\title{
Monocular Optic Neuropathy: Case Unsolved
}

\author{
Filipe Isidro* \\ Ophthalmology Department, Algarve Hospital Centre, Portugal
}

Submission: June 18, 2017; Published: July 17, 2017

*Corresponding author: Filipe Isidro, Ophthalmology Department, Algarve Hospital Centre, Portugal, Email: fisidro86@gmail.com

\section{Case Presentation}

Female patient, 58 years old, unremarkable general medical and ophthalmological history, complains about pulsatile headache, with no irradiation, no specific location, and absence of nausea or vomiting. The headache would not aggravate after Valsalva maneuver and faded without medication. Also, refers vision loss in the right eye (RE) since the beginning of the headache, 10 days before. The best corrected visual acuity (BCVA) was hand movement in the (RE) and 9/10 Snellen scale in the left eye (LE). It was observed a relative afferent pupillary defect (RAPD) graded 3+, no color perception on the RE, Ishihara plates fully read in the LE, no eye movement alterations, and no facial proprioception alterations. The anterior segment had no inflammation signs and phacosclerosis was present in both eyes. Posteriorly, therewas no signs of disc inflammation, vitritis, macular or vascular alterations. Intra-ocular pressure (IOP) was $15 \mathrm{mmHg}$ bilaterally.

\section{Investigations}

Emergency head Computorized Tomography (CT) and Magnetic Resonance Imaging (MRI) with gadolinium were performed to rule out optic pathway lesions or neuritis. ESR, CRP, blood count were performed to exclude Giant Cell Arteritis, wich all came negative [1]. Furthermore, testing for HIV, Syphilis, Hepatitis B and C, IGRA Quantiferon-TB (Tuberculosis), ACE and urinary calcium (Sarcoidosis), ANCA PR3 and MPO (Autoimunity), HLA-B51 (Behçet's disease) and Anti-NMO Aquaporin 4 antibodies (Devic's disease) was completed, with no positive results [2]. Optic disc and macular spectral domain Ocular Computorized Tomography (sdOCT) had no acute alterations. Computorized static perimetry (CSP) was unreliable due to a high percentage of false positive and negative responses, but revealed a deep and general loss of visual sensitivity across all right visual field.

\section{Differential Diagnosis}

At this time, the main differential diagnosis were:

\section{Posterior optic neuropathy (PON)}

Although there was no big abdominal or heart surgery previously, an RAPD graded 3+ and deep visual loss were present [3], without optic disc edema.

\section{Optic neuritis (ON)}

The patient was not young enough to fit the diagnosis of multiple sclerosis or Devic's disease, plus, there were no lesions revealed by the MRI or neurological symptoms, but due to the profundity of visual loss [4], these options had to be considered.

\section{Anterior Ischemic Optic Neuropathy (AION)}

No disc edema was observed, so by definition, this option was excluded [5]. The patient had no risk factors.

\section{Treatment}

After exclusion of infectious possibilities, a $1 \mathrm{Gr}$ metilprednisone/day was administered for 3 days. After this period [6], she was medicated with oral prednisone $1 \mathrm{mgr} / \mathrm{Kg}$ / day for 2 months, and then started to halt it in a slow manner.

\section{Outcome}

The patient improved greatly after 2 months. RE BCVA was 9/10, no RAPD was present, Ishihara plates were completely read and equally fast [7]. RE CSP, wich had initially a Visual Function Index of $2 \%$, presented lastly $65 \%$, with a medium deviation of $-15.42 \mathrm{~dB}$ and pattern stand deviation of $8.45 \mathrm{~dB}$. LE was considered unremarkable. sdOCT revealed RE optic disc atrophy, as the peripapillary nerve fiber layer had a thickness of $60 \mu \mathrm{m}$, and an apparent loss of macular nerve fiber layer thickness [8]. The optic atrophy was observed at the slit lamp.

\section{Discussion}

Initially, due to the absence of optic disc edema, the options considered were posterior to the optic disc, which lead us to think of Multiple Sclerosis and Devic's disease, but the neuro imaging and blood testing ruled out these possibilities. After 2 months, although RE vision had improved, an optic atrophy was evident. It's curious as there was no optic disc edema observed throughout the follow-up, and no occupying-space lesion was identified. Since there was a clinical response to the steroids, ON is a possible diagnosis, although the study was negative. 


\section{References}

1. Hattenhauer MG, Leavitt JA, Hodge DO, Grill R, Gray DT (1997) Incidence of nonarteritic anterior ischemic optic neuropathy. Am J Ophthalmol 123(1): 103-107.

2. Kerr NM, Chew SS, Danesh Meyer HV (2009) Non-arteritic anterior ischaemic optic neuropathy: a review and update. J Clin Neurosci 16(8): 994-1000.

3. Arnold AC (2003) Pathogenesis of nonarteritic anterior ischemic optic neuropathy. J Neuroophthalmol 23(2): 157-163.

4. Miller NR, Newman NJ (2005) Walsh \& Hoyt's Clinical Neuroophthalmology. $6^{\text {th }}($ edn), Lippincott Williams \& Wilkins, USA, pp. 3460-3497.
5. Optic Neuritis Study Group (1997) The 5-year risk of MS after optic neuritis. Experience of the Optic Neuritis Treatment Trial. Neurology 49(5): 1404-1413.

6. Beck RW, Trobe JD, Moke PS, Gal RL, Xing D, et al. (2003) High- and low-risk profiles for the development of multiple sclerosis within 10 years after optic neuritis:experience of the optic neuritis treatment trial. Arch Ophthalmol 121(7): 944-949.

7. Fisher JB, Jacobs DA, Markowitz CE, Galetta SL, Volpe NJ, et al. (2006) Relation of visual function to retinal nerve fiber layer thickness in multiple sclerosis. Ophthalmology 113(2): 324-332.

8. Sellebjerg F, Nielsen HS, Frederiksen JL, Olesen J (1999) A randomized, controlled trial of oral high-dose methylprednisolone in acute optic neuritis. Neurology 52(7): 1479-1484.

\section{Your next submission with Juniper Publishers} will reach you the below assets

- Quality Editorial service

- Swift Peer Review

- Reprints availability

- E-prints Service

- Manuscript Podcast for convenient understanding

- Global attainment for your research

- Manuscript accessibility in different formats

( Pdf, E-pub, Full Text, Audio)

- Unceasing customer service

Track the below URL for one-step submission https://juniperpublishers.com/online-submission.php 